\title{
Combined exposure of diesel exhaust particles and respirable Soufrière Hills volcanic ash causes a (pro-)inflammatory response in an in vitro multicellular epithelial tissue barrier model
}

\author{
Ines Tomašek ${ }^{1,2 *}$, Claire J. Horwell1', David E. Damby ${ }^{3,6}$, Hana Barošová2 ${ }^{2}$ Christoph Geers², Alke Petri-Fink ${ }^{2,5}$,
} Barbara Rothen-Rutishauser ${ }^{2+}$ and Martin J. D. Clift ${ }^{2,4^{*+}}$

\begin{abstract}
Background: There are justifiable health concerns regarding the potential adverse effects associated with human exposure to volcanic ash (VA) particles, especially when considering communities living in urban areas already exposed to heightened air pollution. The aim of this study was, therefore, to gain an imperative, first understanding of the biological impacts of respirable VA when exposed concomitantly with diesel particles.

Methods: A sophisticated in vitro 3D triple cell co-culture model of the human alveolar epithelial tissue barrier was exposed to either a single or repeated dose of dry respirable VA (deposited dose of $0.26 \pm 0.09$ or $0.89 \pm 0.29 \mu \mathrm{g} /$ $\mathrm{cm}^{2}$, respectively) from Soufrière Hills volcano, Montserrat for a period of $24 \mathrm{~h}$ at the air-liquid interface (ALI). Subsequently, co-cultures were exposed to co-exposures of single or repeated VA and diesel exhaust particles (DEP; NIST SRM 2975; $0.02 \mathrm{mg} / \mathrm{mL}$ ), a model urban pollutant, at the pseudo-ALI. The biological impact of each individual particle type was also analysed under these precise scenarios. The cytotoxic (LDH release), oxidative stress (depletion of intracellular GSH) and (pro-)inflammatory (TNF-a, IL-8 and IL-1 $\beta$ ) responses were assessed after the particulate exposures. The impact of VA exposure upon cell morphology, as well as its interaction with the multicellular model, was visualised via confocal laser scanning microscopy (LSM) and scanning electron microscopy (SEM), respectively.

Results: The combination of respirable VA and DEP, in all scenarios, incited an heightened release of TNF- $a$ and IL8 as well as significant increases in IL-1 $\beta$, when applied at sub-lethal doses to the co-culture compared to VA exposure alone. Notably, the augmented (pro-)inflammatory responses observed were not mediated by oxidative stress. LSM supported the quantitative assessment of cytotoxicity, with no changes in cell morphology within the barrier model evident. A direct interaction of the VA with all three cell types of the multicellular system was observed by SEM.

(Continued on next page)
\end{abstract}

\footnotetext{
* Correspondence: ines.tomasek@durham.ac.uk; m.j.d.clift@swansea.ac.uk

${ }^{\dagger}$ Equal contributors

${ }^{1}$ Institute of Hazard, Risk and Resilience, Department of Earth Sciences,

Durham University, Science Labs, Durham DH1 3LE, UK

${ }^{2}$ BioNanomaterials, Adolphe Merkle Institute, University of Fribourg, Chemin

des Verdiers 4, CH-1700 Fribourg, Switzerland

Full list of author information is available at the end of the article
} 
(Continued from previous page)

Conclusions: Combined exposure of respirable Soufrière Hills VA with DEP causes a (pro-)inflammatory effect in an advanced in vitro multicellular model of the epithelial airway barrier. This finding suggests that the combined exposure to volcanic and urban particulate matter should be further investigated in order to deduce the potential human health hazard, especially how it may influence the respiratory function of susceptible individuals (i.e. with pre-existing lung diseases) in the population.

Keywords: Volcanic ash, Diesel exhaust particles, In vitro, Particle co-exposures, Multicellular Human Epithelial Tissue Barrier System, Air-liquid Interface Exposures, (pro-)inflammatory cytokines/chemokines

\section{Background}

With nearly $10 \%$ of the world's population living near a historically active volcano [1], there is long-standing concern over the capacity of respirable-sized volcanic ash (VA) to cause acute and chronic respiratory health effects [2]. Substantial knowledge of the posed respiratory hazard, alongside extensive characterisation of the physicochemical properties of respirable VA, has been obtained in recent years [3, 4], leading to a better understanding of the structure-toxicity relationship [5]. However, with many volcanoes situated near large cities, VA is rarely inhaled in isolation; instead, VA is commonly exposed to the human population concomitantly with additional substances, notably anthropogenic pollution. A prime example of this is Mexico City, which was named by the United Nations as the world's most polluted city in 1992 [6] and sits just $70 \mathrm{~km}$ from the frequently-erupting Popocatepetl volcano.

Exposure to anthropogenic pollution is strongly associated with adverse health effects, predominantly pulmonary and cardiovascular diseases, as well as reduced respiratory health [7-12]. The human population resident in urban areas is particularly affected by high levels of anthropogenic particulate matter (PM) since vehicles are primary emitters of PM, with diesel exhaust particles (DEP) being the main constituent [13]. Yet, currently, limited understanding surrounds the human health hazard associated with the combined exposures (i.e. inhalation) that results from the addition of volcanic PM to the urban environment. Of particular importance is the consideration of how respirable VA may interact with DEP and how this may contribute, or not, to a heightened, potential respiratory hazard.

The aim of the present study, therefore, was to investigate the biological impact of a concomitant exposure to VA (Soufrière Hills volcano, Montserrat) and a standardised DEP sample (National Institute of Standards and Technology's Standard Reference Material (NIST SRM) 2975)) [14] for the first time, using an established, advanced multicellular in vitro model mimicking the human epithelial tissue barrier [15]. The basis for this project stemmed from the British Geological Survey's report to the UK Government on characteristics of a future large, effusive Icelandic eruption, which highlighted the urgent need to evaluate the role of mixing volcanic emissions with anthropogenic pollutants and whether this would affect the individual respiratory hazard of either particle independently [16]. Thus, the current study provides a landmark first assessment of these issues, the findings of which are highly relevant for volcanic health hazard management on a global scale.

\section{Results \\ Particle characterisation}

Particle size analysis of an isolated respirable fraction from the Soufrière Hills ash sample MVO12/7/03 showed that all particles were $<10 \mu \mathrm{m}$. The sample consisted of 12.2, 41.5 and $72.5 \%$ volume of particles with sizes of $<1,<2.5$ and $<4 \mu \mathrm{m}$, respectively (Additional file 1). Specific surface area, as determined by the Brunauer-Emmett-Teller (BET) [17] analysis with nitrogen adsorption, was $3.2 \mathrm{~m}^{2} / \mathrm{g}$.

Characteristics for the NIST SRM 2975 used were previously reported in [18]. Briefly, DEP exhibited a mean diameter of $1.62 \mu \mathrm{m}$ (denoted by number distribution). DEP specific surface area was $91 \mathrm{~m}^{2} / \mathrm{g}$, as determined by BET with nitrogen adsorption.

\section{Nebulisation of VA}

A dry powder insufflator (DP-4, Penn Century, USA) was used to nebulise the respirable fraction of the VA for direct deposition onto the in vitro lung cell culture at the air-liquid interface (ALI). As this was the first study to administer VA at the ALI, an initial dose-dependent analysis of the VA deposition was conducted to determine cell-delivered dose, as well as its biological impact at these different doses. The cell-delivered dose was monitored using an integrated quartz crystal microbalance (QCM) and showed a concentration-dependent deposition of the VA sample (Fig. 1a). The average deposited doses were $0.13 \pm 0.03,0.21 \pm 0.06,0.26 \pm 0.09$ and $0.89 \pm 0.29 \mu \mathrm{g} / \mathrm{cm}^{2}$ (relative to an administered mass of $4,6,8 \mathrm{mg}$ and a repeated administered mass of $8 \mathrm{mg}$, respectfully). The threshold limit for the QCM was $0.09 \mu \mathrm{g} / \mathrm{cm}^{2}$. Scanning electron microscopy (SEM) imaging of the nebulised respirable ash sample $\left(0.89 \pm 0.29 \mu \mathrm{g} / \mathrm{cm}^{2}\right)$ revealed a heterogeneously dispersed deposition of ash particles (Fig. 1b). 

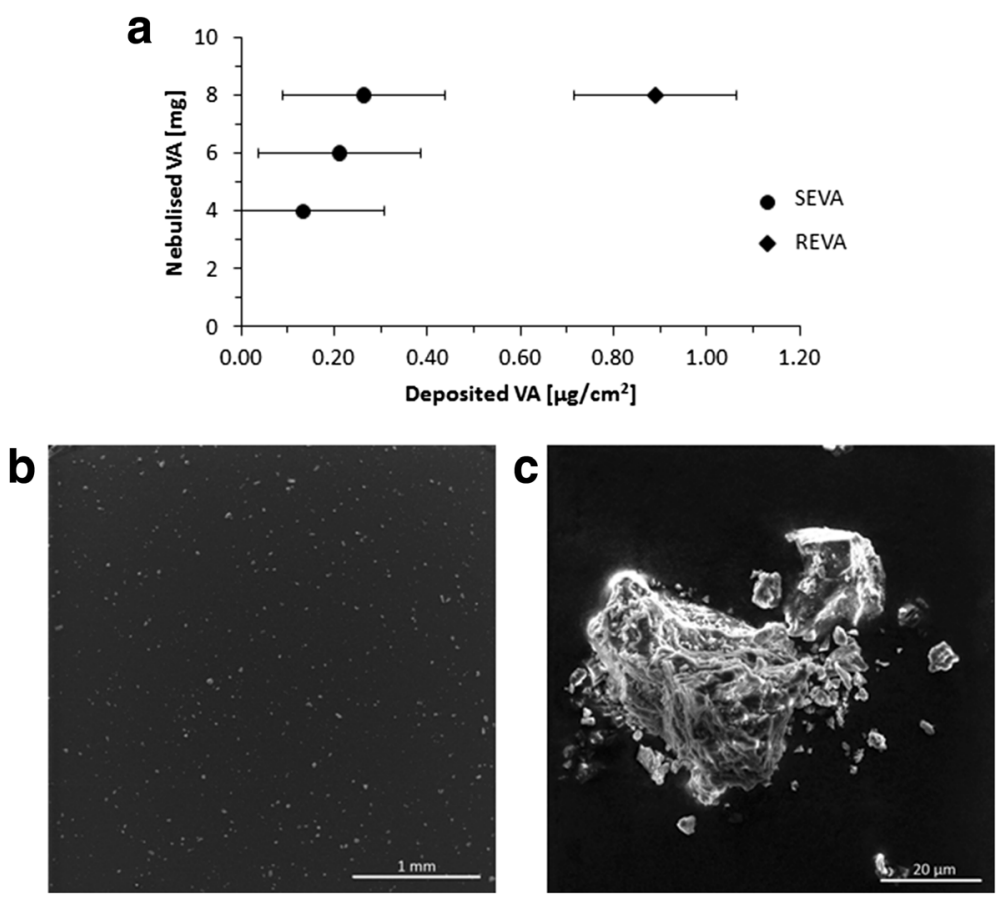

Fig. 1 Deposition of nebulized respirable fraction of volcanic ash. a Average mass deposition $\left(\mu \mathrm{g} / \mathrm{cm}^{2}\right)$ of volcanic ash (VA) quantified using a quartz crystal microbalance (QCM), following nebulisation of dry respirable ash (MVO12/7/03) using a dry powder insufflator (DP-4, Penn Century, USA) under the following conditions: single exposure (SEVA) with $4 \mathrm{mg}(n=14), 6 \mathrm{mg}(n=14)$ or $8 \mathrm{mg}(n=17)$, as well as repeated exposure (REVA) to $8 \mathrm{mg}$ (nebulised $3 \times$ within $15 \mathrm{~min} ; n=9$ ). Data are presented as the mean \pm standard error of the mean. Scanning electron micrographs of nebulized, uncoated ash sample (REVA), show $\mathbf{b}$ heterogeneous particle dispersion (WD: $5.53 \mathrm{~mm}$, MAG: $97 \times$ ) and $\mathbf{c}$ an inset of image (b) (WD: $7 \mathrm{~mm}$, MAG: $3.80 \mathrm{k} \times$ ). Images were collected at $10 \mathrm{kV}$. Scale bars are $1 \mathrm{~mm}$ (b) and 20 um (c)

\section{Particle-cell exposures Volcanic ash}

An initial dose-dependent analysis of cytotoxicity, oxidative stress potential and (pro-)inflammatory response using administered VA masses of 4, 6 and $8 \mathrm{mg}$ (Additional files 2 and 3 ) indicated all doses to be sublethal to the co-culture system. Due to the reliability, as well as a greater and effective deposition of the highest administered mass, it was subsequently used to assess the biological impact of VA as either a single exposure (SEVA; $0.26 \pm 0.09 \mu \mathrm{g} / \mathrm{cm}^{2}$ ) or repeated exposure (REVA; $0.89 \pm$ $0.29 \mu \mathrm{g} / \mathrm{cm}^{2}$ ) towards the in vitro triple cell co-culture model of the epithelial tissue barrier.

As determined via release of the cytosolic enzyme lactate dehydrogenase (LDH), no significant cytotoxicity $(p>0.05)$ was observed after $24 \mathrm{~h}$ following exposure to either SEVA or REVA compared to the negative control (defined as supplemented cell culture medium with no particle exposure) (Fig. 2g). The lack of any cytotoxicity associated with the SEVA and REVA exposures upon the cell cultures was qualitatively supported by the observation that no alteration to cellular morphology occurred, as visualised by laser scanning microscopy (LSM) (Fig. $2 \mathrm{~b}$ and c). It was further observed, by LSM, that the epithelial layer was tightly bound together, forming a monolayer, with cells undergoing mitosis, suggestive of normal homeostasis (Fig. 2b and c). Further assessment of the biochemical impact of SEVA and REVA upon the triple cell co-culture showed no significant $(p>0.05)$ loss in total reduced glutathione (GSH), a key indicator of oxidative stress in vitro [19] (Fig. 3a). Similar, negative effects were also observed for the ability of either SEVA or REVA to elucidate a (pro)inflammatory response, with no significant $(p>0.05)$ production of tumour necrosis factor- $\alpha$ (TNF- $\alpha)$ or interleukin-8 (IL-8) after $24 \mathrm{~h}$ exposure (Fig. 3b and c). It is important to note that, alongside these negative datasets, all positive controls used (i.e. tert-Butyl Hydrogen Peroxide ( $t$ BHP; GSH assay) and lipopolysaccharide (LPS; TNF- $\alpha$ and IL-8)) caused significant increases within the respective biological marker, indicating that the biological model used was responsive for all assay endpoints measured.

\section{Diesel exhaust particles}

Similar findings were observed following exposure of the co-culture to DEP alone, with no significant cytotoxicity (Fig. 2d and g) or changes $(p>0.05)$ to the oxidative stress status of cells observed (Fig. 3a). Importantly, the dose used of DEP was based upon the findings previously shown by Clift et al. [20], who undertook a dose-dependent analysis of the same DEP 

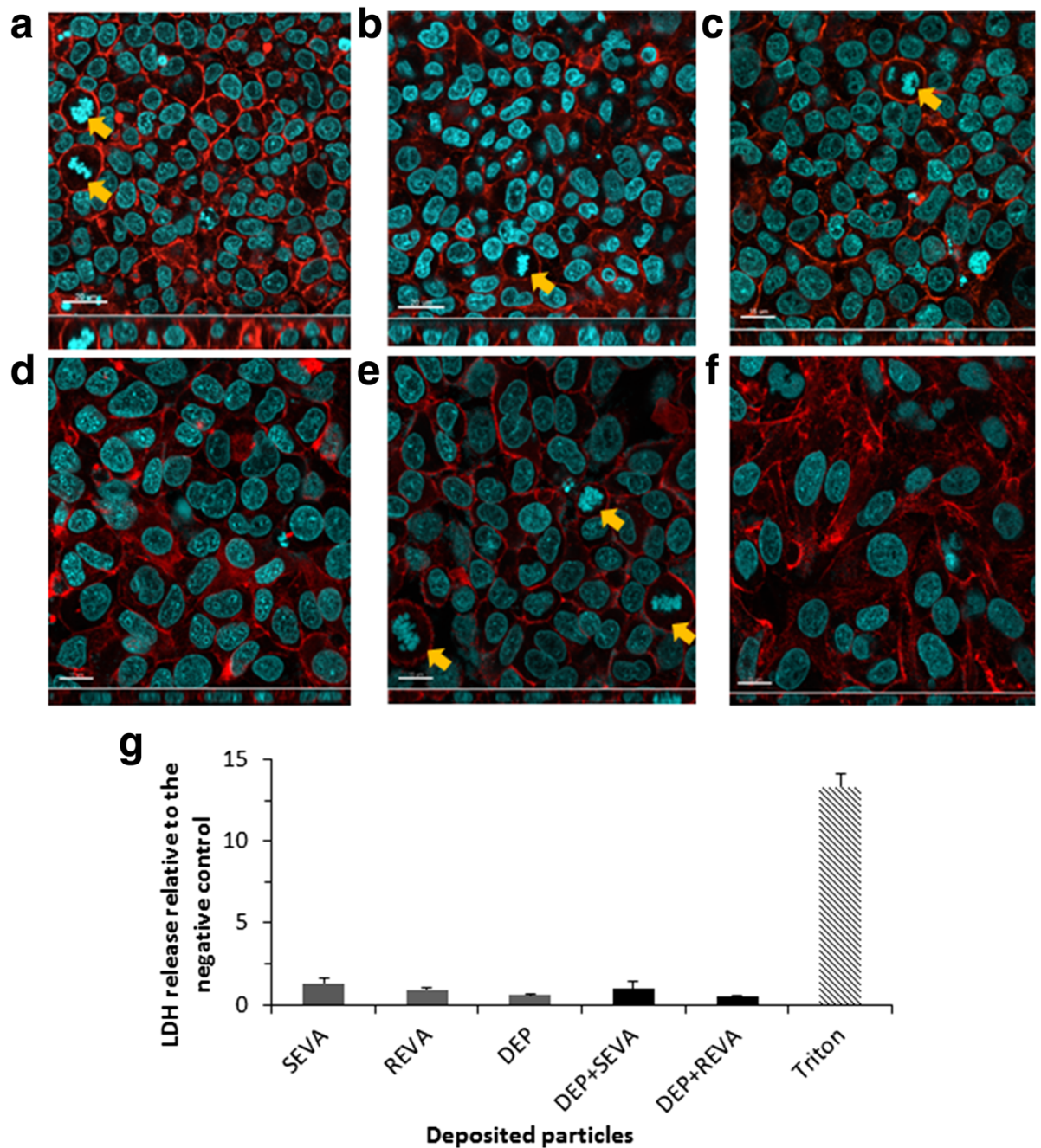

Fig. 2 Cell morphology and cytotoxicity of triple cell co-cultures exposed to volcanic ash and diesel exhaust particles. Confocal laser scanning microscopy (LSM) images show the complete triple cell co-culture (i.e. A549 type-ll 'like' epithelial cell monolayer with human blood monocyte macrophages (MDM) and dendritic cells (MDDC) on the apical and basal sides, respectively) stained for F-actin cytoskeleton (red) and the nuclei (blue). a Control and cultures exposed to $\mathbf{b} 0.26 \pm 0.09 \mu \mathrm{g} / \mathrm{cm}^{2}$ of single exposure to volcanic ash (SEVA), c $0.89 \pm 0.29 \mu \mathrm{g} / \mathrm{cm}^{2}, \mathrm{repeated}$ exposure to volcanic ash (REVA), $\mathbf{d}$ diesel exhaust particles (DEP; $0.02 \mathrm{mg} / \mathrm{mL}$ ), e diesel exhaust particles and $0.26 \pm 0.09 \mu \mathrm{g} / \mathrm{cm}^{2}$ of single exposure to volcanic ash (DEP + SEVA), and $\mathbf{f}$ diesel exhaust particles and $0.89 \pm 0.29 \mu \mathrm{g} / \mathrm{cm}^{2}$ of repeated exposure to volcanic ash (DEP + REVA). Yellow arrows indicate cells undergoing cell division. Scale bars are $20 \mu \mathrm{m}(\mathbf{a}-\mathbf{b})$ and $15 \mu \mathrm{m}$ (c-f). Images were collected at magnification 63X. g Cytotoxicity determined by the release of lactate dehydrogenase $(\mathrm{LDH})$ from the triple cell co-culture following exposure to SEVA, REVA, DEP, DEP + SEVA and DEP + REVA. Data are presented as fold increase relative to the negative control (supplemented cell culture medium only) \pm standard error of the mean. Triton X-100 at 0.2\% in phosphate buffered saline (PBS) acted as the positive assay control. LDH data shown are related to the following repetitions for each exposure: SEVA $n=4$; REVA, DEP, DEP + SEVA and DEP + REVA $n=3$; negative and positive controls $n=8$

sample upon the same co-culture system. Again, the positive assay control, $t \mathrm{BHP}$, showed a significant depletion of GSH in the co-culture system, confirming the observation that the array of sample exposures incited no oxidative stress. Despite these findings, the DEP only exposures to the in vitro multicellular system elicited a significant $(p<0.05)$ interleukin-1 $\beta \quad(\mathrm{IL}-1 \beta)$ and non-significant $(p>0.05)$ TNF- $\alpha$ and IL-8 responses compared to the negative control (Fig. 3b and c).

\section{Combined exposure of SEVA and REVA with DEP}

Combined exposures to DEP and VA (DEP + SEVA, DEP + REVA) also resulted in no significant cytotoxicity (Fig. 2e, $\mathrm{f}$ and g) or changes $(p>0.05)$ to the oxidative stress status of cells (Fig. 3a). It was observed, however, that although the combined exposures did induce an heightened (pro-)inflammatory response in the co-cultures for TNF- $\alpha$ and IL-8 $(p>0.05)$, only a significant $(p<0.05)$ release of IL-1 $\beta$, compared to the negative control, was noted (Fig. 3b-d). 

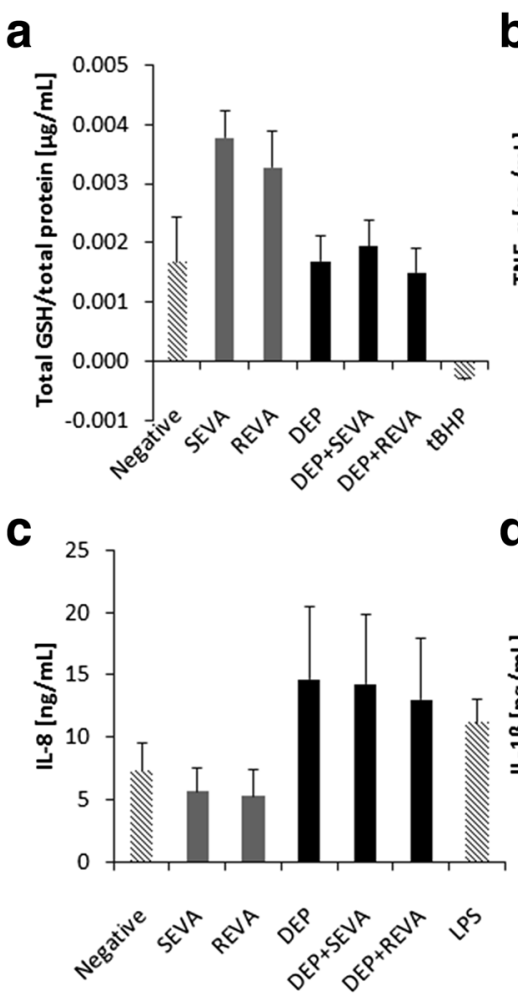

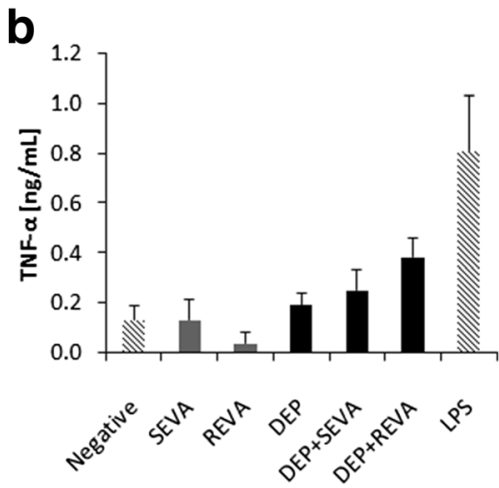

d

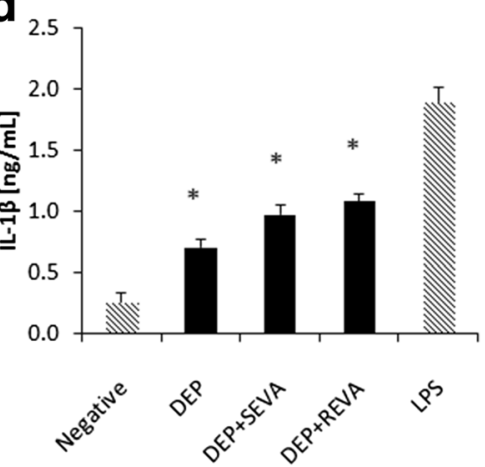

Deposited particles

Fig. 3 Biochemical response of triple cell co-culture system following exposures to volcanic ash and diesel exhaust particles. a Total reduced glutathione (GSH), b tumour necrosis factor-a (TNF-a) release, $\mathbf{c}$ interleukin-8 (IL-8) release and $\mathbf{d}$ interleukin-1 $\beta$ (IL-1 $\beta$ ) release of the triple cell co-culture model after exposure to $0.26 \pm 0.09 \mu \mathrm{g} / \mathrm{cm}^{2}$ of single exposure to volcanic ash (SEVA), $0.89 \pm 0.29 \mu \mathrm{g} / \mathrm{cm}^{2}$ of repeated exposure to volcanic ash (REVA), diesel exhaust particles (DEP; $0.02 \mathrm{mg} / \mathrm{mL}$ ), co-exposure to diesel exhaust particles and $0.26 \pm 0.09 \mu \mathrm{g} / \mathrm{cm}^{2}$ of single exposure to volcanic ash (DEP + SEVA), and co-exposure to diesel exhaust particles and $0.89 \pm 0.29 \mu \mathrm{g} / \mathrm{cm}^{2}$ of repeated exposure to volcanic ash (DEP + REVA). The respective positive assay controls are tert-Butyl Hydrogen Peroxide (tBHP; $250 \mu \mathrm{L}$ of $100 \mathrm{mM}$ ) and lipopolysaccharide (LPS; $100 \mu \mathrm{L}$ of $1 \mu \mathrm{g} / \mathrm{mL})$, added to the apical and basal compartment of the triple cell co-culture, respectively. The negative control was cell culture medium only. Data are presented as the mean \pm standard error of the mean. Data shown are related to the following repetitions for each exposure: SEVA $n=4$; REVA, DEP, DEP + SEVA and DEP + REVA $n=3$; negative and positive controls $n=8 .{ }^{*}$ indicates $p<0.05$

\section{Interaction of VA with triple cell co-cultures}

SEM images of the upper surface of the triple cell coculture exposed to dry VA at the ALI showed that VA was able to directly interact with the macrophage cache of the co-culture system. Interestingly, VA particles were also observed on the basal layer of the triple cell coculture, elucidative of a potential interaction with the MDDC present in this region (Fig. 4).

\section{Discussion}

The purpose of this study was to gain a first understanding as to the potential hazard of a combined VA and DEP exposure to the respiratory system by using a stateof-the-art in vitro approach.

\section{Particle concentrations}

For VA, concentrations of $0.26 \pm 0.09 \mu \mathrm{g} / \mathrm{cm}^{2}$ (SEVA) and $0.89 \pm 0.29 \mu \mathrm{g} / \mathrm{cm}^{2}$ (REVA) were chosen. It is difficult to state how representative these concentrations are in relation to ambient air concentrations following a volcanic eruption, due to the lack of reliable in vivo dosimetry data available and the fact that airborne volcanic ash concentrations are highly dependent upon the distance of a person from the volcano and the dynamics of the eruption itself. In addition, concentrations of respirable ash will be raised during ashfall but, also, later, due to resuspension by wind and human activity in dry conditions, and will dramatically reduce following rain, making average and cumulative exposures difficult to constrain. Searl et al. [21] measured $\mathrm{PM}_{10}$ on Montserrat during a period of frequent ashfall (1997-1999) from the Soufrière Hills volcano and found daily mean concentrations ranging from 0.05 to $1 \mathrm{mg} / \mathrm{m}^{3}$ when plentiful ash was in the environment, and $0.02-0.15 \mathrm{mg} / \mathrm{m}^{3}$ when there was little ash. It is also important to note that personal exposure to volcanic ash is highly influenced by activities undertaken by individuals as well as the general dustiness of the environment; hence concentrations 

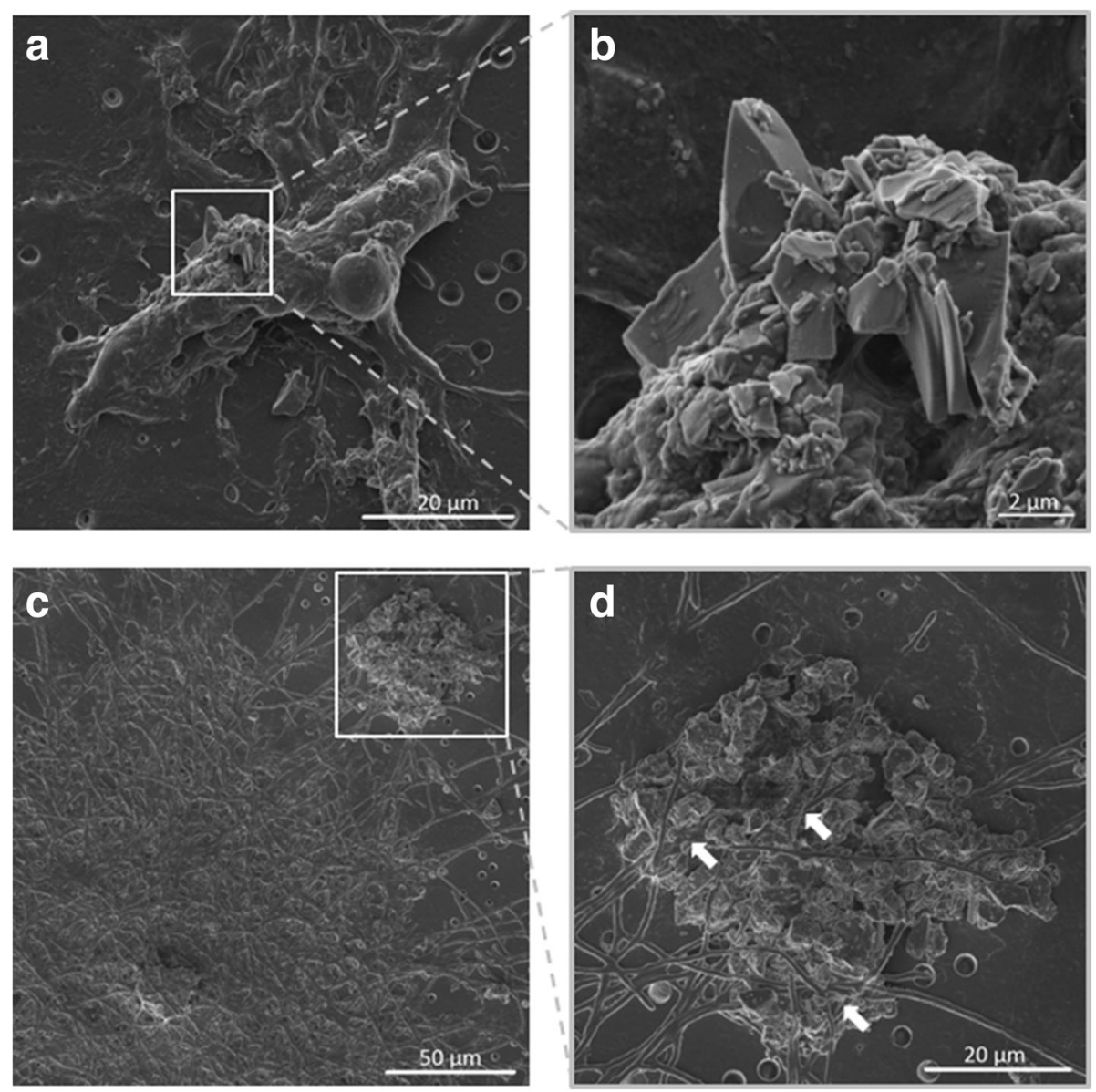

Fig. 4 Interaction of volcanic ash with the triple cell co-culture. Scanning electron micrographs of the triple cell co-culture membrane exposed to $0.26 \pm 0.09 \mu \mathrm{g} / \mathrm{cm}^{2}$ of single exposure to volcanic ash (SEVA), showing direct interaction of VA particles with the different cell types. $\mathbf{a}$ and $\mathbf{b}$ (inset of (a)) show a representative interaction of the human blood monocyte-derived macrophages (MDM) with VA, which appears to be engulfed by the MDM (b). Images $(\mathbf{c})$ and $\mathbf{d}$ (inset of $(\mathbf{c})$ ) show a representative interaction of the human monocyte-derived dendritic cells (MDDC) with the VA particles, which are interacting with the pseudopodia of the MDDC (d; indicated with white arrows). Images were collected at $3 \mathrm{kV}$ and $10 \mathrm{~mm}$ working distance. Scale bars are $20 \mu \mathrm{m}(\mathbf{a}), 2 \mu \mathrm{m}(\mathbf{b}), 50 \mu \mathrm{m}(\mathbf{c})$ and $20 \mu \mathrm{m}$ (d)

associated with activities such as cleaning, or clearing the roads, may be higher than background concentrations, especially considering children [21, 22]. However, the general community will have lower personal exposures than the ambient levels as people will protect themselves (e.g. staying indoors) during ashfall, overnight and at times of high resuspension.

Assuming a daily inhaled air volume for humans to be $25 \mathrm{~m}^{3}$ and an alveolar lung surface area of $c a .100 \mathrm{~m}^{2}$, which correspond to a healthy, moderately-active adult [23], and an alveolar deposition efficiency of about $10 \%$ [24], it can be estimated [25] that the doses used in this study correspond to airborne concentrations which would not be encountered over a $24 \mathrm{~h}$ exposure relative to dry conditions of the highest ash concentration areas during the most active phase of the Soufrière Hills eruption [21]. Thus, from a hazard assessment approach, the doses used in the present study can be considered as a 'worst-case', or a particle overload scenario relative to such an exposure period to humans.

For DEP, a pseudo-ALI approach was adopted as it was not possible to aerosolize the hydrophobic DEP with the dry powder insufflator device, due to the electrostatic nature of DEP in dry powder form. For this reason, VA and DEP could not be applied concomitantly to the cell cultures as a dry powder mixture. Instead, as previously described in [26], a volume of $100 \mu \mathrm{l}$ of DEP suspension in supplemented medium at $0.02 \mathrm{mg} / \mathrm{mL}$ was added to the cells grown on a $4.2 \mathrm{~cm}^{2}$ surface insert. Although these particles highly agglomerate, it was assumed that the majority of the DEP deposited on the cell surface at a dose of $0.5 \mu \mathrm{g} / \mathrm{cm}^{2}$.

Notably, the present study is a first screening of potential adverse effects of combined exposure to VA and DEP, therefore a simple approach of comparing the effect of a combined exposure with the effects of individual particles 
at comparable concentrations and exposure duration was used [27]. Importantly, the effects following exposures to individual particle types were considered, and single exposure data for DEP or VA are now compared to previous investigations using both in vitro and in vivo experiments.

\section{Single particle exposure biological effects}

In the present study, DEP, alone, caused no significant $(p>0.05)$ cytotoxicity or oxidative stress to the coculture. Previous studies also conducted with the same multicellular model have shown that DEP do not enhance the release of LDH, although it has been found that they induce oxidative stress [20, 28, 29]. Variation among studies can be attributed to differences in the applied exposure method $[30,31]$ as previously, the same co-culture as used in the present study was exposed to the same type of DEP (NIST 2975), albeit applied via suspension (in supplemented cell culture medium) to the apical chamber of the insert [20,29], thus initiating different particle-cell interaction kinetics. In the present study, as previously mentioned, a pseudo-ALI approach was used, as previously described [26]. Notably, the lack of cytotoxicity and oxidative stress observed in the present study is contrary to previous findings using monocultures of these cell types [32-36]. This difference can be associated with the cellular interplay exhibited by this multicellular model, where two immune cell types (macrophages and dendritic cells) can directly interact with each other at the epithelium during reactions to particulate antigens [37], thus further highlighting the advantages of using multicellular models. Overall, though, it should be taken into consideration that different cell cultures, DEP compositions, the preparation of particle suspension and doses used in different studies vary, which makes a direct comparison amongst these studies challenging. Nonetheless, in the current study, DEP did cause an increased release of measured (pro-)inflammatory markers (TNF- $\alpha$, IL- 8 and IL-1 $\beta$ ) compared to the negative control (supplemented cell culture medium). These findings concur with previous observations of monoculture in vitro studies, which reported DEP to be highly (pro)-inflammatory $[38,39]$, as well as with studies using the same triple cell co-culture system [20].

Ash from the Soufrière Hills volcano has been extensively studied over the past two decades [40] and is well characterised for its physical and chemical properties, including the sample used here $[3,41,42]$. The biological impact of Soufrière Hills ash has also received increased attention during this time [43-46], particularly due to the substantial crystalline silica present in ash derived from collapses of the Soufrière Hills lava dome (a pile of extruded, viscous lava sitting within the crater) [42]. Previous results from monoculture in vitro studies performed with Soufrière Hills ash are variable, due to the various and numerous different experimental designs employed and endpoints considered as well as the large amount of natural variability amongst ash samples $[2,46]$. Despite this variability, Soufrière Hills ash is generally considered to be non-cytotoxic and have a low oxidative potential, but has the capacity to incite a limited (pro-)inflammatory response. Previous cellspecific studies on macrophages (PMA-differentiated THP-1 monocytes) and A549 epithelial 'like' cells indicated minimal cytotoxicity (measured by LDH release) and GSH depletion following exposures [46], however the response of other antigen presenting cells to VA particles has been largely, to date, uncharacterised. Similar findings have also been noted from in vivo studies [44, 47-49]. In this study, assessment of the biological response from the triple cell co-cultures following VA exposures alone resulted in no significant $(p>0.05)$ cytotoxicity, changes in cellular morphology, oxidative stress or release of (pro-)inflammatory mediators (TNF- $\alpha$ and IL-8). Therefore, the findings of the initial dose-respose analysis of VA exposures alone are largely in congruence with previous research with Soufrière Hills ash $[43,46,50]$.

As evident from the discussion above, all previous in vitro studies performed on VA have used monoculture cell models, where the cell cultures have been immersed in cell medium and VA particles added, already suspended i.e. a pre-mixed sample, in liquid medium. Whilst this approach is commonplace, it does not adequately reflect the physiological condition of a respiratory exposure to VA as particles do not settle in the lung already immersed in liquid (which may affect the surface reactivity of the VA sample). The nebulisation method of VA using the dry powder insufflator (DP-4, Penn Century, USA) has enabled, for the first time for in vitro studies, application of VA to cells in its pristine, dry state. This method represents a more realistic scenario in comparison to all previous studies which used suspended ash in cell medium. The method has also shown good reproducibility, and can, therefore, be considered as a suitable method for conducting realistic in vitro respiratory hazard assessment of VA in future research activities. Furthermore, it has recently been shown that multicellular models can be useful tools in determining the specific (pro-)inflammatory and oxidative stress effects of particles compared to monocultures; as these models additionally take into account intercellular signalling among cells as it would occur in vivo [20].

The observation, by SEM, that the macrophages directly interacted with VA was expected, due to their role in the clearance of foreign material, and previous studies have shown the capacity of macrophages to internalise VA $[46,51]$. The interaction with epithelial cells is not completely unexpected either, due to the surface area that they cover in the alveolar epithelial airway barrier in 
vitro system (insert membrane is $4.2 \mathrm{~cm}^{2}$ with $1 \times 10^{6}$ epithelial cells seeded compared to $5 \times 10^{4}$ macrophages seeded in the co-culture) [15, 37]. It is worth noting that, to the best of the authors' knowledge, this was the first time that dendritic cells have been considered in terms of the biological impact of VA in vitro. The observed interaction of the VA with the MDDC can be hypothesized to occur either through (I) translocation of the VA particles via cell-cell interactions, as previously described for other particle types [37], (II) direct translocation through the pores of the micro-porous membrane insert $(3 \mu \mathrm{m})$, or (III) deposition between the micro-porous membrane outer ridge and the side of the well of the six-well plate during the nebulisation process. Further research is therefore necessary to determine how VA becomes potentially available to interact, or not, with the dendritic cells of the co-culture system, such as through translocation studies previously performed with this $3 \mathrm{D}$ in vitro lung model $[28,52,53]$, as well as to deduce what biological impact this interaction may potentially elucidate.

\section{Co-exposure biological effects}

At sub-lethal concentrations, as with the SEVA, REVA and DEP alone, the combined exposures (DEP + SEVA and DEP + REVA) showed no significant cytotoxicity in the triple cell co-culture. By working in this concentration range, it was therefore possible to study further, mechanistic effects. The impact of any particle type upon the respiratory system is commonly associated with an increased level of oxidative stress [54]. Yet, in the current study, it was observed that no significant differences in oxidative stress levels were evident in any of the combined particle exposures compared to the negative control. In light of these observations, DEP showed no deviation from the negative control but VA treatment increased the relative abundance of GSH, an observation previously attributed to increased production by macrophages (in monoculture) to cope with volcanic ash [46]. Therefore, comparatively, the effect of DEP on GSH levels is greater than the effect seen with VA alone, and the effects noted with the combined exposure scenario could be attributed to the DEP driving an oxidative stress environment in the cell cultures rather than the absence of any oxidative stress. However, to elucidate the underlying mechanisms controlling oxidative stress levels in this combined exposure, further research is needed. Despite the lack of any cytotoxic and limited oxidative stress response following VA and DEP combined exposures, it was found that a heightened (pro)inflammatory response occurred following exposure to respirable VA and DEP when applied as a combined exposure. Focussing firstly on TNF- $\alpha$ release, although there was a greater effect with the DEP + SEVA exposure than that of the individual response for both SEVA and
DEP, the greatest response was observed following the combined exposure of DEP + REVA. It is difficult to state though whether this effect can be described as synergistic in comparison to the two particle treatments alone [27]. Furthermore, the impact of the DEP can also be seen in the combined exposure IL-8 response, as the DEP, DEP + SEVA and DEP + REVA responses are all raised, albeit not significantly $(p>0.05)$, in comparison to the negative control. Given that the apparent driver of the (pro-)inflammatory signal is DEP present in the exposure, this was further assessed by analysing the (pro)inflammatory cytokine IL- $1 \beta$. Release of this marker was significantly higher $(p<0.05)$ in the DEP + REVA scenario compared to the negative control and to DEP alone. The observed higher response of (pro-)inflammatory markers following exposure to the DEP + REVA compared to the DEP + SEVA scenario can be attributed to the effect of the greater combined dose of particles delivered to the cell surface.

In summary, the current study provides a first insight into the biological effects of combined exposure to VA and an urban pollutant (DEP) and implies a potentially greater hazard of simultaneously inhaling both particle types. The observations indicate that combined exposure to VA and DEP induces a (pro-)inflammatory response in cells at the respiratory epithelial tissue barrier, but it is not yet clear whether this effect is directly driven by the individual particle-cell interactions, secondary toxicology mechanisms incited via the particles' physicochemical characteristics, or through particle-particle interactions leading to the combined effect noted. It is known that increased release of (pro-)inflammatory mediators may augment, as well as prolong, inflammatory reactions and, if the exposure persists, can result in chronic inflammation [38]. Airway inflammation not only promotes the development of lung diseases, but it may increase the susceptibility to acute cardiovascular disease [55]. Thus, the significance of these findings lies in the potential effects on respiratory health that this combined exposure may elucidate. These initial results are being used to inform future, planned work investigating chemical interactions between particles and the particle/ gas/volatile mixtures of complete vehicle exhaust $[56,57]$ as well as volcanic emissions.

\section{Conclusion}

The findings in the present study show that exposure to sub-lethal concentrations of VA with an urban pollutant (i.e. DEP) can promote a heightened and significantly increased (pro-)inflammatory response in vitro, absent of mediation by oxidative stress. The observed effects of the combined exposures are of further significance as, in some circumstances, they are greater than the response noted for DEP or VA, independently. It is envisaged that, 
in the event of future eruptions, the findings of this study will serve for a better understanding of the potential respiratory risk posed by combined exposure to urban pollution and VA towards human health. These findings will provide the basis for further investigations into the mechanisms driving the heightened (pro-)inflammatory response, in order to deduce the specific human health hazard, as well as how it may influence the respiratory function of susceptible individuals (i.e. with preexisting lung diseases) in the population.

\section{Methods}

\section{Chemicals and reagents}

All chemicals and reagents were purchased from Sigma Aldrich (Switzerland), unless otherwise stated.

\section{Particle samples \\ Volcanic ash}

Source Ash from a dome-collapse ash-fall deposit of Soufrière Hills volcano, Montserrat (erupted and ash sample collected on 12 July 2003) was used (MVO12/7/ 03). The ash on Montserrat erupts into a very clean atmosphere (occasionally polluted by transfer of dust from the Sahara), so was chosen as a pristine example of ash which had no prior interaction with anthropogenic pollution. The bulk ash has previously been extensively characterised [3, 4, 41], and contains substantial quantities of respirable particles (cumulative volume \% is 22.5 and 11.5 for $<10 \mu \mathrm{m}$ and $<4 \mu \mathrm{m}$, respectively) [3] and is rich in crystalline silica (13.5 weight \%) [4].

Sample preparation A respirable fraction of VA was isolated using a Sioutas Cascade Impactor (SKC Inc., $U S A$ ) and Leland Legacy sample pump (SKC Inc., USA) attached to a gravitational separation chamber. VA was introduced into an airstream established by operating the pump at a constant flow rate of $5 \mathrm{~L} / \mathrm{min}$. Aerosolised particles then entered the separation chamber where particles above a theoretical spherical aerodynamic diameter of $5 \mu \mathrm{m}$ sedimented in accordance with Stoke's law, calculated for a particle density of $1.0 \mathrm{~g} / \mathrm{cm}^{3}$ in the system. These parameters have been empirically observed to produce an appropriate respirable-sized fraction in this set up. Remaining airborne particles were then sampled by the Impactor, which was assembled without impaction stage filters to enable sample recovery. Size-fractionated samples were then collated for use in characterisation and toxicity assays. Separation of the respirable fraction from the sedimented ash was conducted upon the same subsample on three different occasions, and then combined in order to maximise the recovery of respirable material needed for the study.

\section{Characterisation of VA respirable fraction}

Particle size distribution analyses of isolated respirable samples were performed using a Coulter LS230 (Coulter Corporation, USA) in water without sonication. Data were analysed according to the Mie theory of light scattering [58]. Results are the mean of three consecutive runs of the sample. Runs were $60 \mathrm{~s}$ each.

Surface area was determined using samples dried overnight at $105{ }^{\circ} \mathrm{C}$ according to the BET method [17], and analysed by nitrogen adsorption measurements at $-196.15{ }^{\circ} \mathrm{C}$ using a Gemini III 2375 surface area analyser (Micromeritics Instrument Corporation, USA). Results are the mean of three independent measurements of the sample.

\section{Nebulisation of $V A$ respirable fraction}

Respirable VA was nebulised over the cells using a dry powder insufflator (Model DP-4; PennCentury Inc., Philadelphia, USA). The use of the dry powder insufflator was based upon the method previously described by Bihari et al. [59]. Briefly, the ash was loaded into a sample chamber and then pushed through the device by small pulses of air administered to the device using a $10 \mathrm{~mL}$ commercial air syringe. The ash was discharged as a cloud from the end of a delivery tube and, in this way, nebulised over the cell culture plate located below the delivery tube within a closed nebulisation chamber. The quantification of deposited material was monitored by a QCM (with a detection limit $90 \mathrm{ng} / \mathrm{cm}^{2}$, AT-cut quartz, $5 \mathrm{MHz}$ resonance frequency; Stanford Research Systems, USA) also located within the nebulisation chamber. Specifically, as material settles onto the QCM, the frequency of the crystal changes $(\Delta \mathrm{F})$. Calculated from the recorded frequency values before and after deposition of material, this $\Delta \mathrm{F}$ value $(\mathrm{Hz})$ is converted to deposited mass per area $\left(\mu \mathrm{g} / \mathrm{cm}^{2}\right)$ as described in [31]. In addition, as previously highlighted in [26], the deposition pattern can possibly change across each well of the six-well culture plate used. Analysis of the data showed that there was no difference in the deposition pattern across each well of the six-well culture plates used (data not shown).

Scanning electron microscopy Nebulised respirable ash was imaged, uncoated, by a Mira3 LM (Tescan, Czech Republic) FE-SEM, using a secondary electron (SE) detector in order to visualise particle deposition and morphology.

\section{Diesel exhaust particles}

Source Standard diesel exhaust particulate (DEP; NIST SRM 2975) was used. The key characteristics of this standard sample have previously been reported $[14,59]$. 
Sample preparation To produce a suspension of DEP, $1 \mathrm{mg}$ of dry DEP was suspended in $1 \mathrm{~mL}$ cell culture medium RPMI 1640 (supplemented with 1\% L-Glutamine, $1 \%$ Penicillin/Streptomycin and 10\% fetal bovine serum). The pre-mixed solution was subsequently sonicated for 90 min at $37 \mathrm{kHz}$ at $37{ }^{\circ} \mathrm{C}$. This stock suspension of DEP was diluted with supplemented RPMI 1640 medium to a working concentration of $0.02 \mathrm{mg} / \mathrm{mL}$.

\section{Hazard assessment Lung cell cultures}

All in vitro exposure experiments in this study were conducted with an established 3D triple cell co-culture model of the human epithelial tissue barrier cultured at the ALI $[15,52,60]$. This system has previously been described in detail [61]. Briefly, the model consists of a layer of human alveolar type II-like epithelial cells (A549) with human monocyte-derived macrophages (MDM) on the apical side (upper chamber) and monocyte-derived dendritic cells (MDDC) on the basal side (lower chamber). A549 epithelial cells were cultured at a density of $1 \times 10^{6}$ cells per insert on BD Falcon cell culture inserts (high pore density PET membranes, $4.2 \mathrm{~cm}^{2}$ growth area, $3.0 \mu \mathrm{m}$ pore size; Beckton Dickinson AG, Switzerland).

Human blood monocytes were isolated from different, individual buffy coats received from the Swiss blood donation service (Bern, Switzerland) (i.e. different donor for each exposure), using $\mathrm{CD} 14^{+}$MicroBeads as described previously [57]. Due to this, variations in the background among different sets of cell cultures were expected to occur. The cell culture densities of MDM and MDDC were $5 \times 10^{4}$ cells/insert and $25 \times 10^{4}$ cells/insert, respectively. Quantification of the cell-cell ratio for this co-culture system has previously been analysed and reported [37]. Co-cultures were incubated for $24 \mathrm{~h}$ under suspension conditions in order to allow cell-cell habituation. Subsequently cell culture medium was extracted from the apical layer to allow formation of the ALI over an extra $24 \mathrm{~h}$ period at $37^{\circ} \mathrm{C}$, $5 \% \mathrm{CO}_{2}$ prior to particle exposures.

\section{Lung cell exposures}

VA exposures In the approach used in this study, VA was administered as dry powder onto the upper surface of the co-culture at the ALI $[37,60]$ using a dry powder insufflator (Model DP-4; PennCentury Inc., Philadelphia, USA). Compared to the conventional particle suspension exposure, exposure at the ALI has been found to be a more sensitive in vitro exposure method, as it exhibits similar cellular responses at lower doses [30]. In addition, changes to the surface chemistry, morphology and size of the particles, which might affect the toxicological response of the system, are minimised.
As part of the initial dose dependent analysis to determine the optimal dose to use for VA in the combined exposure scenario, feed masses to the dry powder insufflator of 4, 6 and $8 \mathrm{mg}$ of VA were used in a single dose exposure scenario. The corresponding dose that was deposited onto the cells was $0.13 \pm 0.03,0.21 \pm 0.06$ and $0.26 \pm 0.09 \mu \mathrm{g} / \mathrm{cm}^{2}$ for 4,6 , and $8 \mathrm{mg}$ starting (feed) mass, respectively. Additionally, repeated exposure to the highest dose $(8 \mathrm{mg})$ was used in order to increase particle mass deposition onto the cells, as $8 \mathrm{mg}$ was the feed maximum per nebulisation. A mass of $8 \mathrm{mg}$ was loaded into the dry powder insufflator and nebulised over the cells three times within a time period of $\sim 15 \mathrm{~min}$. The average mass deposited in the repeated exposure scenario was $0.89 \pm 0.29 \mu \mathrm{g} / \mathrm{cm}^{2}$.

DEP exposures DEP were used in a pseudo-ALI exposure experiment, as previously described [26]. Briefly, a total volume of $100 \mu \mathrm{l}$ of DEP at $0.02 \mathrm{mg} / \mathrm{mL}$ suspended in supplemented medium was added to the apical compartment of the triple cell co-culture model at the ALI, grown on a $4.2 \mathrm{~cm}^{2}$ surface trans-membrane insert. Upon assumption that the majority of the DEP would deposit homogeneously on the cell surface, the applied concentration would equate to a deposited concentration of $0.5 \mu \mathrm{g} /$ $\mathrm{cm}^{2}$. It is important to note that this methodology was used due to the fact that dry DEP were found to be unsuitable for nebulisation using the dry powder insufflator due to their electrostatic nature as a dry powder (data not shown).

VA and DEP combined exposures Directly after the exposure to DEP, the highest dose (chosen based upon the biological impact noted from the dose-response analysis and the efficiency of each dose deposited on the coculture from the dry powder insufflator) of VA was applied, either as SEVA or REVA exposure, using the dry powder insufflator as previously described above in the section entitled 'Lung Cell Exposures; VA Exposures'.

Post-exposure and sampling Each exposure was followed by a $24 \mathrm{~h}$ incubation period at $37{ }^{\circ} \mathrm{C}$ and $5 \% \mathrm{CO}_{2}$. After this, supernatants were collected and stored at either $4{ }^{\circ} \mathrm{C}$ or $-80{ }^{\circ} \mathrm{C}$ until biochemical assays could be performed. In addition, insert membranes were fixed and prepared for immunofluorescent labelling or SEM microscopy, as described below.

\section{Biochemical assays \\ Cytotoxicity}

LDH Release Cytotoxicity, indicated by cell membrane damage, was determined by measuring the release of the intracellular enzyme lactate dehydrogenase (LDH) into the co-culture supernatant, assessed using an LDH 
cytotoxicity detection kit (Roche Applied Science, Mannheim, Germany) according to the manufacturer's guidelines. The test was conducted in triplicate for each replication. The following repetitions for each exposure were conducted: SEVA $n=4$; REVA, DEP, DEP + SEVA and DEP + REVA $n=3$; negative and positive controls $n=8$. Absorbance was determined at $490 \mathrm{~nm}$ after $10 \mathrm{~min}$ using a microplate reader (Bio-Rad, Switzerland), with a reference wavelength set at $630 \mathrm{~nm}$. As a positive control, co-cultures were treated with $100 \mu \mathrm{l}$ of $0.2 \%$ Triton X-100 in phosphate buffered saline (PBS) on the apical side and incubated for $24 \mathrm{~h}$ at $37^{\circ} \mathrm{C}, 5 \% \mathrm{CO}_{2}$.

Cell morphology After the post-incubation period of $24 \mathrm{~h}$, triple cell co-cultures were prepared for imaging via laser scanning microscopy (LSM). Cell membranes were fixed with $3 \%$ paraformaldehyde for $15 \mathrm{~min}$ at room temperature and then transferred to $0.1 \mathrm{M}$ glycine in phosphate buffered saline (PBS) for $10 \mathrm{~min}$. Samples were then washed $\mathrm{x} 3$ with $\mathrm{PBS}$, and treated with $0.2 \%$ Triton X-100 for $15 \mathrm{~min}$ at room temperature to permeabilise the cell membrane for immunofluorescent staining. Subsequently, samples were stained with phalloidinrhodamine (R-415; Molecular Probes, Life Technologies Europe B.V., Zug, Switzerland) in a 1:100 dilution to label the F-actin cytoskeleton, and with 1:100 dilution of 4',6diamidin-2-phenylindol (DAPI) at $1 \mu \mathrm{g} / \mathrm{mL}$ in $0.2 \%$ Triton $\mathrm{X}-100+1 \%$ BSA in PBS to highlight the cell nuclei. Visualisation of the samples was conducted with an inverted confocal LSM 710 (Axio Observer.Z1, Carl Zeiss, Switzerland) at a magnification of 63x. Representative images (z-stacks) were recorded at three independent fields of view for each sample (three independent samples were analysed $(n=3)$ ) and were further processed using the 3D reconstruction software IMARIS (Bitplane AG, Zurich, Switzerland).

\section{Oxidative stress}

The total amount of reduced glutathione (GSH) in samples was quantified using a glutathione assay kit (Cayman Chemical Company, Ann Arbor, Michigan, USA) according to the manufacturer's instructions. The detected concentrations of GSH are reported relative to the concentrations of total protein of each corresponding sample (determined by the Pierce BCA Protein Assay kit (Pierce Protein Research Products, Thermo Scientific, Rockford, Illionis, USA)), according to the manufacturer's instructions. The negative control was cell culture medium only. As a positive control, co-cultures were treated with $250 \mu \mathrm{l}$ of $100 \mathrm{mM}$ tert-Butyl Hydrogen Peroxide $(t \mathrm{BHP})$ on the apical side and incubated for $24 \mathrm{~h}$ at $37{ }^{\circ} \mathrm{C}, 5 \%$ $\mathrm{CO}_{2}$. For each replication, analysis was conducted in triplicate. The following repetitions for each exposure were conducted: SEVA $n=4$; REVA, DEP, DEP + SEVA and DEP + REVA $n=3$; negative and positive controls $n=8$.

\section{Chemokine/cytokine release}

The (pro-)inflammatory response was investigated by quantifying tumour necrosis factor- $\alpha$ (TNF- $\alpha)$, interleukin8 (IL-8) and interleukin-1 $\beta$ (IL-1 $\beta$ ) release from the coculture system into the basal cell culture well via enzymelinked immunosorbent assays (ELISA DuoSet Development Kit, RED Systems, Minneapolis, Minnesota, USA) according to the manufacturer's protocol. The concentrations were determined spectrophotometrically at $450 \mathrm{~nm}$ using a microplate reader (Bio-Rad, Switzerland). Lipopolysaccharide (LPS, from E-coli at $1 \mu \mathrm{g} / \mathrm{mL}$ ) was applied at a volume of $1.2 \mathrm{~mL}$ in the bottom compartment of the co-cultures and served as the positive control for TNF$\alpha$, IL- 8 and IL- $1 \beta$ induction. The negative control was cell culture medium only. Analyses were conducted in triplicate for each replicate. The following repetitions for each exposure were conducted: SEVA $n=4$; REVA, DEP, DEP + SEVA and DEP + REVA $n=3$; negative and positive controls $n=8$.

\section{VA:lung cell interactions in vitro Scanning electron microscopy}

Co-cultures exposed to SEVA were fixed with 3\% paraformaldehyde for $15 \mathrm{~min}$ at room temperature and then sequentially washed with 20,40 and $60 \%$ methanol for 5 min, 80\% methanol for 3 min and washed 5 times with $100 \%$ methanol for $30 \mathrm{~s}$. Samples were then dried in a vacuum desiccator over a $48 \mathrm{~h}$ period. Samples were then carbon coated and subsequently imaged with a Mira3 LM (Tescan, Czech Republic) FE-SEM, using an InBeam detector on a rotated stage $\left(60^{\circ}\right)$.

\section{Data and statistical analysis}

All data are presented as the mean \pm standard error of the mean, deriving from three individual experiments $(n=3)$ unless otherwise stated. All statistical analyses were performed using SPSS statistical software (IBM SPSS Statistics for Windows, Version 22.0, Armonk, NY, USA). Statistical significance was deduced through the use of a one-way analysis of variance (ANOVA), based upon normal distribution of the datasets. Subsequent Tukey's post hoc tests were conducted to determine the specific statistical significance between the VA, DEP, DEP + SEVA and DEP + REVA exposures to the negative control (supplemented cell culture medium only). The alpha value was set at 0.05 .

\section{Additional files}

Additional file 1: Particle size distribution of the isolated respirable fraction of Soufrière Hills volcanic ash. Determined by a Beckman Coulter LS230 PSD analyser (Coulter Corporation, USA). Data are the mean of $n=3$. (TIF $30 \mathrm{~kb}$ ) 
Additional file 2: Cell morphology and cytotoxicity of the triple cell co-culture exposed to different single exposure doses of volcanic ash. Confocal laser scanning microscopy (LSM) images show the F-actin cytoskeleton (red) and the nuclei (blue) of (a) control and cultures exposed to (b) $0.13 \mu \mathrm{g} / \mathrm{cm}^{2}$, (c) $0.21 \mu \mathrm{g} / \mathrm{cm}^{2}$, and (d) $0.26 \mu \mathrm{g} / \mathrm{cm}^{2}$ of respirable volcanic ash. Yellow arrows indicate cells undergoing cell division. Scale bars are $20 \mu \mathrm{m}$. Images were collected at magnification 63x. (e) Cytotoxicity as determined by the release of lactate dehydrogenase $(\mathrm{LDH})$ from the triple cell co-culture following single exposure to $0.13 \mu \mathrm{g} /$ $\mathrm{cm}^{2}, 0.21 \mu \mathrm{g} / \mathrm{cm}^{2}$, and $0.26 \mu \mathrm{g} / \mathrm{cm}^{2}$ of respirable volcanic ash. Data are presented as fold increase relative to the negative control (cell culture medium only) \pm standard error of the mean. Triton X-100 at $0.2 \%$ in phosphate buffered saline (PBS) acted as the positive assay control. $\mathrm{LDH}$ data shown are related to the following repetitions for each exposure: SEVA $n=4$; negative and positive controls $n=8$. (TIF $524 \mathrm{~kb}$ )

Additional file 3: Biochemical response of the triple cell co-culture following exposures to different doses of volcanic ash. (a) Total reduced glutathione (GSH), (b) tumour necrosis factor-a (TNF-a) release, and (c) interleukin-8 (IL-8) release of the triple cell co-culture model after single exposure to $0.13 \mu \mathrm{g} / \mathrm{cm}^{2}, 0.21 \mu \mathrm{g} / \mathrm{cm}^{2}$, and $0.26 \mu \mathrm{g} / \mathrm{cm}^{2}$ of respirable volcanic ash. The respective positive assay controls are tert-Butyl Hydrogen Peroxide (tBHP; $250 \mu \mathrm{L}$ of $100 \mathrm{mM}$ ) and lipopolysaccharide (LPS; $100 \mu \mathrm{L}$ of $1 \mu \mathrm{g} / \mathrm{mL}$ ), added to the apical and bottom compartment of the triple cell co-culture, respectively. The negative control was cell culture medium only. Data are presented as the mean \pm standard error of the mean. Data shown are related to the following repetitions for each exposure: SEVA $n=4$; negative and positive controls $n=8$. (TIF $51 \mathrm{~kb}$ )

\section{Abbreviations}

ALI: Air-liquid interface; BET: Brunauer-Emmett-Teller; DEP: Diesel exhaust particles; ELISA: Enzyme-linked immunosorbent assay; GSH: Total reduced glutathione; IL-1ß: Interleukin-1 beta; IL-8: Interleukin-8; LDH: Lactate dehydrogenase; LPS: Lipopolysaccharide; LSM: Laser scanning microscopy; MDDC: Monocyte derived dendritic cells; MDM: Monocyte derived macrophages; NIST SRM: National Institute of Standards and Technology's Standard Reference Material; PBS: Phosphate buffered saline; PM: Particulate matter; QCM: Quartz crystal microbalance; REVA: Repeated exposure volcanic ash; SE: Secondary electron; SEM: Scanning electron microscopy; SEVA: Single exposure volcanic ash; tBHP: tert-Butyl Hydrogen Peroxide; TNF-a: Tumour necrosis factor - alpha; VA: Volcanic ash

\section{Acknowledgements}

The authors would like to acknowledge Ms. Yuki Umehara for her assistance with all cell culture, as well as the BioNanomaterials group at the Adolphe Merkle Institute.

\section{Funding}

IT is financially supported by the VERTIGO Marie Curie Initial Training Network (ITN), funded through the European Seventh Framework Programme (FP7) under Grant Agreement number 607905. The authors would also like to thank the Swiss National Science Foundation (Grant No. 310030_159847/1) as well as the Adolphe Merkle Foundation for additional financial support. DED was supported by the AXA Research Grant "Risk from volcanic ash in the Earth system" and ERC Advanced Investigator Grant No. 247076 (EVOKES).

\section{Availability of data and materials}

All data and materials are specifically referenced within the manuscript. These are all openly available.

\section{Authors' contributions}

IT participated in the design of the study, carried out all biological - based experimentation and drafted the manuscript. $\mathrm{CJH}$ devised the project and was, as well as DED, AP-F, BR-R and MJDC, involved in the planning and technical advisory of the study. DED isolated the respirable fraction of VA and performed PSD and BET characterisation analysis. HB was involved in performing LSM imaging. CG was involved in SEM imaging. MJDC was the project leader; he was involved in planning the design of the study, has intellectually accompanied all experimental work, made substantial contributions to the analysis and interpretation of the data. CJH, DED, BR-R and
MDJC have been involved in critically revising the manuscript for important intellectual content. All authors have confirmed approval of the final version of the submitted manuscript.

\section{Competing interests}

The authors declare no competing interests. The authors are entirely responsible for the data included in the present manuscript and furthermore for its written text.

\section{Consent for publication}

All authors have read and approved the manuscript for publication. There are no outstanding issues or requirements.

\section{Ethics approval and consent to participate}

Ethics regarding the use of human blood was considered under Swiss Federal Law. There were no requirements to obtain 'consent to participate', as it was not applicable for this study.

\section{Author details}

${ }^{1}$ Institute of Hazard, Risk and Resilience, Department of Earth Sciences, Durham University, Science Labs, Durham DH1 3LE, UK. ${ }^{2}$ BioNanomaterials, Adolphe Merkle Institute, University of Fribourg, Chemin des Verdiers 4, $\mathrm{CH}-1700$ Fribourg, Switzerland. ${ }^{3}$ Department of Earth and Environmental Sciences, Section for Mineralogy, Petrology and Geochemistry, Ludwig-Maximilians-Universität München, Theresienstrasse 41, 80333 Munich, Germany. ${ }^{4}$ In Vitro Toxicology Group, Institute of Life Sciences, Swansea University Medical School, Singleton Park Campus, Swansea SA2 8PP, Wales, UK. ${ }^{5}$ Chemistry Department, University of Fribourg, Chemin des Musee, CH-1700 Fribourg, Switzerland. ' United States Geological Survey, 345 Middlefield Road, Menlo Park, CA 94025, USA.

Received: 17 June 2016 Accepted: 29 November 2016

Published online: 12 December 2016

\section{References}

1. Small C, Naumann T. The global distribution of human population and recent volcanism. Global Environ Change B Environ Hazard. 2001;3(3):93-109.

2. Horwell CJ, Baxter PJ. The respiratory health hazards of volcanic ash: a review for volcanic risk mitigation. Bull Volcanol. 2006;69(1):1-24. doi:10.1007/s00445-006-0052-y.

3. Horwell CJ. Grain-size analysis of volcanic ash for the rapid assessment of respiratory health hazard. J Environ Monit. 2007;9(10):1107-15. doi:10.1039/010583p.

4. Horwell CJ, Le Blond JS, Michnowicz SAK, Cressey G. Cristobalite in a rhyolitic lava dome: evolution of ash hazard. Bull Volcanol. 2010;72(2):249-53. doi:10.1007/s00445-009-0327-1.

5. Horwell CJ, Williamson BJ, Donaldson K, Le Blond JS, Damby DE, Bowen L. The structure of volcanic cristobalite in relation to its toxicity; relevance for the variable crystalline silica hazard. Part Fibre Toxicol. 2012;9:44. doi:10.1186/1743-8977-9-44.

6. WHO/UNEP. Urban Air pollution in megacities of the world World Health Organization, United Nations environment programme. Oxford: Blackwell; 1992.

7. Pope CA, Burnett RT, Thun MJ, Calle EE, Krewski D, Ito K, et al. Lung cancer, cardiopulmonary mortality, and long-term exposure to fine particulate air pollution. JAMA. 2002;287(9):1132-41. doi:10.1001/jama.287.9.1132.

8. Schulz H, Harder V, Ibald-Mulli A, Khandoga A, Koenig W, Krombach F, et al. Cardiovascular effects of fine and ultrafine particles. J Aerosol Med. 2005; 18(1):1-22. doi:10.1089/jam.2005.18.1.

9. Dominici F, Peng RD, Bell ML, Pham L, McDermott A, Zeger SL, et al. Fine particulate air pollution and hospital admission for cardiovascular and respiratory diseases. JAMA. 2006;295(10):1127-34. doi:10.1001/jama.295.10.1127.

10. Pope III CA, Turner MC, Burnett RT, Jerrett M, Gapstur SM, Diver WR, et al. Relationships between fine particulate Air pollution, cardiometabolic disorders, and cardiovascular mortality. Circ Res. 2015;116(1):108-U258. doi:10.1161/circresaha.116.305060

11. Ibald-Mulli A, Wichmann HE, Kreyling W, Peters A. Epidemiological evidence on health effects of ultrafine particles. J Aerosol Med. 2002;15(2):189-201. doi:10.1089/089426802320282310.

12. Wichmann HE, Peters A. Epidemiological evidence of the effects of ultrafine particle exposure. Phil Trans R Soc A: Mathematical, Physical and Engineering Sciences. 2000;358(1775):2751-69. 
13. WHO. Health effects of transport-related air pollution. Copenhagen: World Health Organization; 2005.

14. Singh P, DeMarini DM, Dick CA, Tabor DG, Ryan JV, Linak WP, et al. Sample characterization of automobile and forklift diesel exhaust particles and comparative pulmonary toxicity in mice. Environ Health Perspect. 2004;112(8):820.

15. Rothen-Rutishauser BM, Kiama SG, Gehr P. A three-dimensional cellular model of the human respiratory tract to study the interaction with particles. Am J Respir Cell Mol Biol. 2005;32(4):281-9. doi:10.1165/rcmb.2004-01870C.

16. Loughlin SC, Aspinall WPA, Vye-Brown C, Baxter PJ, Braban C, Hort M, et al. Large-magnitude fissure eruptions in Iceland: source characterisation. 2012. BGS Open File Report, OR/12/098.

17. Brunauer S, Emmett PH, Teller E. Adsorption of gases in multimolecular layers. J Am Chem Soc. 1938;60:309-19. doi:10.1021/ja01269a023.

18. Technology NloS. Certificate of Analysis: Standard Reference Material 2975, Diesel Particulate Matter (Industrial Forklift), vol. 11. USA: NIST, Department of Commerce; 2013.

19. Clift MJ, Boyles MS, Brown DM, Stone V. An investigation into the potential for different surface-coated quantum dots to cause oxidative stress and affect macrophage cell signalling in vitro. Nanotoxicology. 2010;4(2):139-49.

20. Clift MJ, Endes C, Vanhecke D, Wick P, Gehr P, Schins RP, et al. A comparative study of different in vitro lung cell culture systems to assess the most beneficial tool for screening the potential adverse effects of carbon nanotubes. Toxicol Sci. 2014;137(1):55-64.

21. Searl A, Nicholl A, Baxter P. Assessment of the exposure of islanders to ash from the Soufriere Hills volcano, Montserrat, British West Indies. Occup Environ Med. 2002;59(8):523-31.

22. Horwell CJ, Sparks RSJ, Brewer TS, Llewellin EW, Williamson BJ. Characterization of respirable volcanic ash from the Soufriere Hills volcano, Montserrat, with implications for human health hazards. Bull Volcanol. 2003; 65(5):346-62. doi:10.1007/s00445-002-0266-6.

23. ICRP. Human Respiratory Tract Model for Radiological Protection. ICRP Publication 66. Ann. ICRP 24. 1994. (1-3).

24. Lahde A, Gudmundsdottir SS, Joutsensaari J, Tapper U, Ruusunen J, Ihalainen $\mathrm{M}$, et al. In vitro evaluation of pulmonary deposition of airborne volcanic ash. Atmos Environ. 2013;70:18-27. doi:10.1016/j.atmosenv.2012. 12.048.

25. Paur H-R, Cassee FR, Teeguarden J, Fissan H, Diabate S, Aufderheide M, et al. In-vitro cell exposure studies for the assessment of nanoparticle toxicity in the lung-A dialog between aerosol science and biology. J Aerosol Sci. 2011;42(10):668-92.

26. Endes C, Schmid O, Kinnear C, Mueller S, Camarero-Espinosa S, Vanhecke D, et al. An in vitro testing strategy towards mimicking the inhalation of high aspect ratio nanoparticles. Part Fibre Toxicol. 2014;11(1):1.

27. Cassee FR, Groten JP, Bladeren PJ, Feron VJ. Toxicological evaluation and risk assessment of chemical mixtures. Crit Rev Toxicol. 1998;28(1):73-101.

28. Lehmann AD, Blank F, Baum O, Gehr P, Rothen-Rutishauser BM. Diesel exhaust particles modulate the tight junction protein occludin in lung cells in vitro. Part Fibre Toxicol. 2009:6(26):1-14

29. Mueller L, Riediker M, Wick P, Mohr M, Gehr P, Rothen-Rutishauser B. Oxidative stress and inflammation response after nanoparticle exposure: differences between human lung cell monocultures and an advanced three-dimensional model of the human epithelial airways. J R Soc Interface. 2010;7:S27-40. doi:10.1098/rsif.2009.0161.focus.

30. Holder AL, Lucas D, Goth-Goldstein R, Koshland CP. Cellular response to diesel exhaust particles strongly depends on the exposure method. Toxicol Sci. 2008;103(1):108-15.

31. Lenz AG, Karg E, Lentner B, Dittrich V, Brandenberger C, Rothen-Rutishauser $B$, et al. A dose-controlled system for air-liquid interface cell exposure and application to zinc oxide nanoparticles. Part Fibre Toxicol. 2009;6:32. doi:10.1186/1743-8977-6-32.

32. Jantzen $K$, Roursgaard M, Desler C, Loft S, Rasmussen L, Møller P. Oxidative damage to DNA by diesel exhaust particle exposure in co-cultures of human lung epithelial cells and macrophages. Mutagenesis. 2012;27(6):693-701. doi:10.1093/mutage/ges035.

33. Li N, Sioutas C, Cho A, Schmitz D, Misra C, Sempf J, et al. Ultrafine particulate pollutants induce oxidative stress and mitochondrial damage. Environ Health Perspect. 2003;111(4):455.

34. Bai Y, Suzuki AK, Sagai M. The cytotoxic effects of diesel exhaust particles on human pulmonary artery endothelial cells in vitro: role of active oxygen species. Free Radic Biol Med. 2001;30(5):555-62.
35. Pan C-JG, Schmitz DA, Cho AK, Froines J, Fukuto JM. Inherent redox properties of diesel exhaust particles: catalysis of the generation of reactive oxygen species by biological reductants. Toxicol Sci. 2004;81(1):225-32.

36. Xiao GG, Wang M, Li N, Loo JA, Nel AE. Use of proteomics to demonstrate a hierarchical oxidative stress response to diesel exhaust particle chemicals in a macrophage cell line. J Biol Chem. 2003;278(50):50781-90.

37. Blank F, Rothen-Rutishauser B, Gehr P. Dendritic cells and macrophages form a transepithelial network against foreign particulate antigens. Am J Respir Cell Mol Biol. 2007;36(6):669-77. doi:10.1165/rcmb.2006-0234OC.

38. Schwarze PE, Totlandsdal Al, Lag M, Refsnes M, Holme JA, Ovrevik J. Inflammation-related effects of diesel engine exhaust particles: studies on lung cells in vitro. Biomed Res Int. 2013. doi:10.1155/2013/685142.

39. Donaldson K, Tran L, Jimenez LA, Duffin R, Newby DE, Mills $N$, et al. Combustion-derived nanoparticles: a review of their toxicology following inhalation exposure. Part Fibre Toxicol. 2005;2:10. doi:10.1186/1743-8977-2-10.

40. Baxter PJ, Searl AS, Cowie HA, Jarvis D, Horwell CJ. Evaluating the respiratory health risks of volcanic ash at the eruption of the Soufriere Hills Volcano, Montserrat, 1995 to 2010. Eruption of Soufriere Hills Volcano, Montserrat from 2000 to 2010, vol. 39. 2014. p. 407-25. doi:10.1144/m39.22.

41. Horwell CJ, Fenoglio I, Fublni B. Iron-induced hydroxyl radical generation from basaltic volcanic ash. Earth Planet Sci Lett. 2007;261(3-4):662-9. doi:10.1016/j.epsl.2007.07.032.

42. Horwell CJ, Hillman SE, Cole PD, Loughlin SC, Llewellin EW, Damby DE, et al. Controls on variations in cristobalite abundance in ash generated by the Soufriere Hills Volcano, Montserrat in the period 1997 to 2010. Eruption of Soufriere Hills Volcano, Montserrat from 2000 to 2010, vol. 39. 2014. p. 399-406. doi:10.1144/m39.21.

43. Cullen RT, Searl A. Preliminary toxicological hazard assessment of Montserrat volcanic ash: in vitro cytotoxicity. Edinburgh: Institute of Occupational Medicine; 1998. p. 13. P752/200.

44. Cullen RT, Jones AD, Miller BG, Donaldson K, Davis JMG, Wilson M, et al. Toxicity of volcanic ash from Montserrat. Edinburgh: Institute of Occupational Medicine; 2002. p. 55. IOM TM/02/01.

45. Horwell CJ, Baxter PJ, Hillman SE, Calkins JA, Damby DE, Delmelle P, et al. Physicochemical and toxicological profiling of ash from the 2010 and 2011 eruptions of Eyjafjallajokull and Grimsvotn volcanoes, Iceland using a rapid respiratory hazard assessment protocol. Environ Res. 2013;127:63-73. doi:10.1016/j.envres.2013.08.011.

46. Damby DE, Murphy FA, Horwell CJ, Raftis J, Donaldson K. The in vitro respiratony toxicity of cristobalite-bearing volcanic ash. Environ Res. 2016;145:74-84.

47. Berube KA, Jones TP, Housley DG, Richards RJ. The respiratory toxicity of airborne volcanic ash from the Soufriere Hills volcano, Montserrat. Mineral Mag. 2004;68(1):47-60. doi:10.1180/0026461046810170.

48. Housley DG, Berube KA, Jones TP, Anderson S, Pooley FD, Richards RJ. Pulmonary epithelial response in the rat lung to instilled Montserrat respirable dusts and their major mineral components. Occup Environ Med. 2002;59(7):466-72. doi:10.1136/oem.59.7.466.

49. Lee SH, Richards RJ. Montserrat volcanic ash induces lymph node granuloma and delayed lung inflammation. Toxicology. 2004;195(2-3): 155-65. doi:10.1016/j.tox.2003.09.013.

50. Wilson MR, Stone V, Cullen RT, Searl A, Maynard RL, Donaldson K. In vitro toxicology of respirable Montserrat volcanic ash. Occup Environ Med. 2000; 57(11):727-33. doi:10.1136/oem.57.11.727.

51. Monick MM, Baltrusaitis J, Powers LS, Borcherding JA, Caraballo JC, Mudunkotuwa I, et al. Effects of Eyjafjallajokull volcanic ash on innate immune system responses and bacterial growth in vitro. Environ Health Perspect. 2013;121(6):691-8.

52. Rothen-Rutishauser B, Muhlfeld C, Blank F, Musso C, Gehr P. Translocation of particles and inflammatory responses after exposure to fine particles and nanoparticles in an epithelial airway model. Particle and fibre toxicology, vol. 4. 2007. p. 9. doi:10.1186/1743-8977-4-9.

53. Endes C, Mueller S, Kinnear C, Vanhecke D, Foster EJ, Petri-Fink A, et al. Fate of Cellulose Nanocrystal Aerosols Deposited on the Lung Cell Surface In Vitro. Biomacromolecules. 2015;16(4):1267-75. doi:10.1021/acs.biomac.5b00055.

54. Donaldson K, Stone V, Borm PJ, Jimenez LA, Gilmour PS, Schins RP, et al. Oxidative stress and calcium signaling in the adverse effects of environmental particles (PM 10). Free Radic Biol Med. 2003:34(11):1369-82.

55. Donaldson K, Stone V, Seaton A, Macnee W. Ambient particle inhalation and the cardiovascular system: potential mechanisms. Environ Health Perspect. 2001;109 suppl 4:523-7. 
56. Mueller L, Comte P, Czerwinski J, Kasper M, Mayer ACR, Gehr P, et al. New exposure system to evaluate the toxicity of (scooter) exhaust emissions in lung cells in vitro. Environ Sci Technol. 2010;44(7):2632-8. doi:10.1021/es903146g.

57. Steiner S, Mueller L, Popovicheva OB, Raemy DO, Czerwinski J, Comte P, et al. Cerium dioxide nanoparticles can interfere with the associated cellular mechanistic response to diesel exhaust exposure. Toxicol Lett. 2012;214(2): 218-25. doi:10.1016/j.toxlet.2012.08.026.

58. Mie G. Beiträge zur Optik trüber Medien, speziell kolloidaler Metallösungen. Ann Phys. 1908:330(3):377-445.

59. Bihari P, Vippola M, Schultes S, Praetner M, Khandoga AG, Reichel CA, et al. Optimized dispersion of nanoparticles for biological in vitro and in vivo studies. Part Fibre Toxicol. 2008;5(1):14.

60. Blank F, Rothen-Rutishauser BM, Schurch S, Gehr P. An optimized in vitro model of the respiratory tract wall to study particle cell interactions. J Aerosol Med. 2006;19(3):392-405. doi:10.1089/jam.2006.19.392.

61. Lehmann A, Brandenberger C, Blank F, Gehr P, Rothen-Rutishauser B. In: ML Y, RS L, editors. A 3D Model of the Human Epithelial Airway Barrier. Methods in Bioengineering: Alternative Technologies to Animal Testing. Boston: Artech House; 2010.

\section{Submit your next manuscript to BioMed Central and we will help you at every step:}

- We accept pre-submission inquiries

- Our selector tool helps you to find the most relevant journal

- We provide round the clock customer support

- Convenient online submission

- Thorough peer review

- Inclusion in PubMed and all major indexing services

- Maximum visibility for your research

Submit your manuscript at www.biomedcentral.com/submit 